\title{
Environmental Health Monitoring: A Pragmatic Approach
}

\section{Savariar Vincent}

Loyola Institute of Frontier Energy, Chennai, India

${ }^{*}$ Corresponding author:Dr. Vincent, Dean of Research, Loyola College \& Director, Loyola Institute of Frontier Energy, Chennai - 600 034, Tamil Nadu, India, Tel: +91-9445-87-8319; Fax: +91-044-2817-5566; E-mail: svincentloyola@gmail.com

Received date: October 24, 2014, Accepted date: December 18, 2014, Published date: December 22, 2014

Copyright: (c) 2014 Vincent S. This is an open-access article distributed under the terms of the Creative Commons Attribution License, which permits unrestricted use, distribution, and reproduction in any medium, provided the original author and source are credited.

\begin{abstract}
Eco benign environment, wherein human race survives and evolves, comprises the interaction of biotic and abiotic systems. Maintaining such environment in view of drastically changing human practices due to increased industrialization, urbanization and modernization is an urgent necessity for the global human community. The responsibility to protect the environment as well as to make it suitable for sustaining human life with well-being propels research-based implementation of best industrial and environmental practices. The nature of strategies and research designed for arriving eco-benign solutions to the challenges of environmental protection widely varies with different fields of industry. It is important to note that the intervention of environmental friendly strategies for making hazard and disease free environment is inevitable in all spheres of life, and the research on green solutions envisaged for management of environmental resources is the need of hour. Hence, in this review, we highlight three socially important environmental research areas such as impact of toxicity of metal pollutants in aquatic biological systems with special reference to fish as a bioindicator, mosquito control by bioinsecticides, and management of disease and disaster management by Geographical Information Systems (GIS) that are of our areas of contribution. Though these areas are viewed as different domains, they share an unique feature among themselves i.e. the crisis in water management affecting environment and health. The review also attempts to discuss about the possible biointervention solutions to address the challenges in water management in terms of pollution.
\end{abstract}

Keywords: Metal toxicity; Aquatic health; Biomonitoring; Metallothionein; Bioinsecticides; GIS; Drainage

\section{Changing Quality of Aquatic Life}

Quality of life in aquatic system is determined by the characteristics of biotic resources and their interactions that are complex and dynamic. Naturally, there is a self-balance between the biotic resources and their interactions both in quantitative and qualitative aspects and the balance is affected when new elements are introduced to the system. Especially, the elements introduced into the system have toxic properties; the aquatic system is under threat of quality degradation that seriously affects global biodiversity. Aquatic system today is polluted by industrial effluents comprising organic and synthetic chemical substances, heavy metals, dyes, oil etc; house hold wastes such as detergents and drainage; e-wastes, pesticides from agricultural lands, spillage of oil from ships etc. These pollutants of both biodegradable and non-biodegradable change the water qualities such as colour, odour, surface tension, thermal properties, conductivity, density, $\mathrm{pH}$ etc [1]. The acidic and alkali pollutants destroy most invertebrates and microorganisms [2]. Due to increased anthropogenic activities, aquatic organisms are continuously exposed to the elevated levels of metal concentration that the levels not previously encountered. The metal contaminants in aquatic systems usually remain either insoluble or suspension form and finally tend to settle down at the bottom are taken up by the organisms. The progressive and irreversible accumulation of these metals in various organs of marine creatures leads to metal related physiological impairing in the long run because of their toxicity and persistence, thereby endangering the aquatic biota and other organisms [3]. Metals and pesticides, in particular, have an inclination to accumulate, undergo food chain magnification and exhibit chronic toxicity [4]. It is also important to monitor the bioaccumulation of these metals and pesticides in a living system (fish) and assess the possible impact on human health due to consumption [5]. There is also a need to intervene with options such as reduction in the use of heavy metals, replacement of toxic metals by nonmetallic substances in process and product, metal recovery and recycling and reducing the metal release in process as well as from product through leaching to minimize the damage by metal toxicity caused to the aqua-biotic system. Development and use of novel bioinsecticides will not only eliminate the ill effects of biomagnification but also helps to sustain the environment for bioproductivity.

\section{Metal Toxicity in Aqua-Biotic Systems}

Aquatic organisms readily absorb heavy metals through respiratory surfaces, mucus covering gills, where it gradually diffuse into to the binding sites, adsorption through body surface and cell wall where it diffuse through cell membrane and accumulate in cells during ion exchange. The metal which has a relatively high density and toxic at low quantity is referred as 'heavy metal', e.g., arsenic (As), lead $(\mathrm{Pb})$, mercury $(\mathrm{Hg})$, cadmium $(\mathrm{Cd})$, chromium $(\mathrm{Cr})$, thallium $(\mathrm{Tl})$, etc. Some 'trace elements' are also known as heavy metals, e.g., copper $(\mathrm{Cu})$, selenium $(\mathrm{Se})$ and zinc $(\mathrm{Zn})$. They are essential to maintain the body metabolism, but they are toxic at higher concentrations. Bioaccumulation of metals reflects the amount ingested by the organism, the way in which the metals are distributed amongst the different tissues and the extent to which the metal is retained in each tissue. Also, metal accumulation depends upon other factors such as species, age, exposure time, temperature, salinity, metal and physiological factors [6,7]. Heavy metal accumulation dominantly occurs in metabolically active tissues such as liver and kidney [8]. There are many studies on fish response to metal contamination and 
fish is generally recognized as one of the most sensitive indicator for environmental livability studies for assessing any change in aquatic system due to pollutants $[9,10]$. In fish tissues, metals form complexes and may then be readily excreted. In some cases, however, the metals may alter the biochemical composition of tissues, rendering it unfit for human consumption.

\section{XenoticPotential of Zinc And Nickel on Aquatic Life}

Zinc and nickel are nutritionally essential trace elements for all organisms, and hence either deficiency or toxicity symptoms arise respectively when too little or too much accumulation occur. Effluents of textile, paint and tanning industries were reported to contain 120 to $160 \mathrm{mg} / \mathrm{L}$ of zinc and nickel metals [11]. Zinc is an integral part of certain enzymes, e.g., carbonic anhydrase, carboxypeptidase, and several hydrogenases. It was reported that zinc concentrations exceeding $330 \mathrm{mg} / \mathrm{L}$ may be lethal to fish [12]. The study also reported that the general trend of zinc accumulation in various tissues of Silver carp fish Hypophthalmichthys molitrix was found to be gills (460 $\mathrm{mg} / \mathrm{L})<$ liver $(513 \mathrm{mg} / \mathrm{L})<$ intestine $(562 \mathrm{mg} / \mathrm{L})<$ kidney $(828 \mathrm{mg} / \mathrm{L})$ after exposed to sublethal concentration of $6 \mathrm{mg} / \mathrm{L}$ for 30 days. It was found that zinc was most toxic in soft water of $\mathrm{pH} 4-6$ and 8-9 and that excess zinc was precipitated in mucus and epithelial layer of gills that resulted in mortality due to damage of the gill epithelium [13]. Histopathological effects in gills, liver, intestine and kidney tissues of Silver carp after zinc sulphate exposure revealed that all the above tissues were affected due to zinc accumulation. Pathological features such as hypertrophy, necrosis, vacuolization, disintegration of cells, pyknotic nuclei and haemolysis were observed in all tissues with slight variations in features [14].

In a study, it was reported that the exposure of Silver carp to $\mathrm{Zn}$ and $\mathrm{Ni}$ at the sublethal concentrations of $6.8 \mathrm{mg} / \mathrm{L}$ and $5.7 \mathrm{mg} / \mathrm{L}$ respectively resulted in the synthesis of stress proteins in the gill, liver and kidney tissues with the reduction in the synthesis of other proteins compared with that of protein profile of unexposed fish controls $[15,16]$. Other heavy metals such as cadmium also was known to evoke the expression of stress proteins in fish and marine invertebrates [17]. $\mathrm{Ni}$ is introduced into the hydrosphere by removal from the atmosphere, by surface run-off by discharge of industrial, municipal and mining waste, and also following natural erosion of soils and rocks [18]. Ni has not been considered a broadscale global contaminant; however, ecological changes, such as a decrease in the number and diversity of species, have been observed near Ni emitting sources [19]. Fresh water levels of $\mathrm{Ni}$ are typically about $1-10 \mu \mathrm{g} / \mathrm{L}$ in unimpact areas [20] and $\mathrm{Ni}$ concentrations in highly contaminated fresh waters may reach as high as several hundred to $1000 \mu \mathrm{g} / \mathrm{L}$ [21].

The kidney plays a principal role in the accumulation, detoxification, and excretion of $\mathrm{Ni}$ and it is considered to be a target organ for Ni toxicity [22]. The assessment of genotoxic potential of $\mathrm{Ni}$ and $\mathrm{Zn}$ after exposing Silver carp at the above stated sublethal concentrations revealed chromosomal aberrations such as polyploidy, dicentric chromosome, acentric fragment, variation in the length of chromosomal arms, chromatid break, chromosomal clumping and centromeric fusion [23]. The frequency of these aberrations were higher in fish exposed to Nickel Chloride when compared Zinc Sulphate. Toxic metals exhibiting genotoxic effects were known to form reactive oxygen species as well as electrophilic free radical metabolites that interact with DNA to cause disruptive changes [24]. $\mathrm{Ni}$ could bind to DNA and proteins in cells in vitro and to chromatin in vivo. Such binding to macromolecules could be correlated to the ability of $\mathrm{Ni}$ compounds to interfere with DNA synthesis and to induce slight increases in chromosomal alterations, as well as its mutagenic action $[25,26]$. It was reported that $\mathrm{Ni}$-induced abnormal DNA repair is a mechanism for carcinogenesis [27].

\section{Mode of Chromium Toxicity and its Bioremediation Mechanism}

Chromium compounds have widespread uses in steel production, wood preservation, leather tanning, metal corrosion inhibition, paints and pigments, metal plating and other industrial applications. Trivalent and Hexavalent forms are the dominant oxidation states of chromium that exist in the environment. $\mathrm{Cr}$ (VI), a carcinogen, is highly toxic to all forms of life. Cr (III), an essential micronutrient for many higher organisms, is relatively insoluble in water and 100 times less toxic than $\mathrm{Cr}$ (VI) [28]. In our early study, we investigated the effect of $\mathrm{Cr}$ on acid (ACP) and alkaline phosphatase (ALP) activities from various tissues such as gill, intestine, liver and kidney after exposing Indian major carp fish Catla catla to the sublethal concentration in the range of 20 to $32 \mathrm{mg} / \mathrm{L}$ [29]. It was found that though both ACP and ALP in these tissues were inhibited to the extent of 40 to $70 \%$, intestine was the most affected tissue and higher inhibition was observed for ALP in these tissues than ACP. Besides, it was observed that decline in the function of phosphatases due to $\mathrm{Cr}$ inhibition resulted in lysosome injury reflecting cellular stress. ALP is involved in transphophorylation reactions and its inhibition might be related to the ability of toxicant to alter cell configuration by binding to the membrane system.

In another study, we reported that exposure of fish (Catla catla) to sublethal concentration of $\mathrm{Cr}$ resulted in reduction in overall metabolism due to depletion of food utilization parameters such as consumption, assimilation, gross and net production, biomass and metabolic rates [30]. Elevated levels of egestion were observed in the study that reflected poor energy assimilation.

We have also reported that untreated tannery effluents having high $\mathrm{Cr}$ concentration when loaded to the aquatic system, they affected gross (GPP) and net primary productivity (NPP) of major aquatic macrophytes such as Hydrilla verticillata and Ceretophyllum demersum due to creation of metal influenced imbalance in the photosynthetic machinery [31]. An increase in the respiratory rate of macrophytes in the study suggested increased metabolism and extra energy demand under effluent stress condition. Primary production in aquatic system is the most important biological phenomenon on which an array of life depends for energy either directly or indirectly.

Studies were also conducted on macrophytes such as Caldesia paranassipolia for assessing its potential of the affinity to $\mathrm{Cr}$ and its use on $\mathrm{Cr}$ bioremediation as the aquatic plant has the potential to survive under various ecological conditions and has the ability to uptake heavy metals [32]. The findings of the study suggested that the absorption of $\mathrm{Cr}$ was about $75 \%$ when the plant was exposed to water having $\mathrm{Cr}$ concentration of $10000 \mathrm{ppm}$ for 15 days. The morphology of the plant after exposed to $\mathrm{Cr}$ in the stated condition did not reveal much change except slight leaf withering and weakening of stem.

In an another Cr bioremediation study, the potential of microbes such as alkalophilic Bacillus sp. was assessed for their ability to reduce $\mathrm{Cr}$ (VI) since detoxification under alkaline conditions derive importance due to alkaline nature of many industrial effluents [33]. The chromium resistant bacteria isolated from tannery effluent contaminated soil was found to grow and reduce $\mathrm{Cr}$ (VI) to $\mathrm{Cr}$ (III) up 
to $100 \%$ at an alkaline $\mathrm{pH} 9.0$ as evidenced by XPS and FT-IR spectra. The chromate reductase assay confirmed that constitutive membrane bound enzymes mediated the reduction, and the rate of reduction was reduced when the $\mathrm{pH}$ is reduced to below 7.0 due to secretion of acidic metabolites of growth. Several Cr (VI) detoxification studies mediated by bacteria were reported at neutral/near-neutral $\mathrm{pH}$; but, very few studies were reported under alkaline condition [34,35]. Cr (VI) was found to affect colony morphology and sporulation ability in Bacillus $s p$. which may also affect $\mathrm{Cr}$ bioremediation process. Confocal Laser Scanning Microscope (CLSM) studies revealed changes in the production of exopolymeric substances of bacteria exposed to $\mathrm{Cr}$ and these substances are essential for absorption of $\mathrm{Cr}$ [28].

\section{Arsenic and Cadmium Toxicity - A Threat to Aquatic System}

The arsenic (As) is commonly present in air, water, soil and all living tissues. It is at the 20th abundant element in the earth's crust, 14th in seawater and 12th in human body. It is reported as a carcinogen, and causes foetal death and malformations in many mammal species. Contamination of aquatic environment by arsenicals and their impact on the aquatic organisms has now emerged as a serious environmental problem [36]. In aquatic systems, inorganic arsenic can occur in both $\mathrm{As}^{3+}$ and $\mathrm{As}^{5+}$ oxidation states. The level of $\mathrm{As}^{3+}$ to $\mathrm{As}^{5+}$ depends on the influences of $\mathrm{pH}$, metal sulfide and sulfide ion concentrations, iron concentration, temperature, salinity, and the distribution of the biota in an aquatic ecosystem.

Generally, the inorganic As compounds are more toxic and carcinogenic than organic compounds, and trivalent As (arsenites, As ${ }^{+3}$ ) are more toxic than pentavalent As (arsenates, $\mathrm{As}^{+5}$ ). Most of the As compounds are used in manufacture of agricultural products such as insecticides, herbicides, fungicides, algaecides, wood preservatives, and growth stimulants for plants and animals. The atmospheric emissions from smelters, coal-fired power plants and arsenical herbicide sprays; water contaminated by mine tailings, smelter wastes and natural mineralization; and diet, especially from consumption of marine biota, all cause As toxicity [37].

In freshwater fish, As can be present in two different oxidation states, as arseno-sugars and arseno-lipids, these two differ in their toxicity which is supposed to be responsible for the pathophysiology of arsenic [38]. Arsenobetaine and arsenocholine are non-toxic organic forms of arsenic present in fish. The majority of total arsenic in fish tissue is present as arsenobetaine [39]. In a study on the spotted snakehead fish Channa punctatus, it was observed that when the high concentration $(2 \mathrm{mM})$ of sodium arsenite $(\mathrm{NaAsO})$ affected these fishes, they died within $3 \mathrm{~h}$. The chromosomal DNA of liver cells were fragmented which indicated that $\mathrm{NaAsO}$ might have caused death of those cells through apoptosis [40]. It was reported that As severely affected liver of tilapia (Oreochromis mossambicus) while treating at sublethal concentration of $28 \mathrm{ppm}$. The liver was the most affected organ and the histopathological studies of liver tissue showed focal lymphocytic and macrophage infiltration, congestion, vacuolization and shrinkage of hepatocytes, necrosis and nuclear hypertrophy [41]. In a study, we evaluated the toxic effects of arsenic trioxide $\left(\mathrm{Ar}_{2} \mathrm{O}_{3}\right)$ to freshwater fish $C$. carpio at different median lethal concentration levels and assessed its influences on the expression of metallothionein (MT) activity in liver and kidney [42]. It was found that the acute exposure resulted in instantaneous death of fish because of As-induced increases in mucus production, causing suffocation, or direct detrimental effects on gill epithelium besides increasing MT protein expression. Oxidative stress-induced apoptosis is a possible mechanism of arsenic toxicity in a zebra fish Danioreri oliver cell line [43].

Cadmium $(\mathrm{Cd})$ is a transition heavy metal widely used in manufacture of semiconductors, integrated circuits, electroplating, and photoelectric appliances. The metal is released into the environment during manufacturing processes such as etching, wet polishing, and cleaning operations, which may produce much potentially hazardous waste. Cd was found to exhibit lethal effect at $0.05 \mathrm{mg} / \mathrm{L}$ concentration on fresh water swamp shrimp Macrobrachium nipponense [44]. It was reported that Cd increased the expression of oxidative stress biomarkers such as catalase, Glutathione-S-peroxidase, glutathione reductase and lipid peroxidase in response to increase in reactive oxygen species (ROS) in liver and gills of fish Gambusia holbrooki [45]. Blood being a sensitive indicator of stress, and white cells being involved in the immune defence of the organism, the state of health of fish Catla catla was found to be stressed under the toxic influence of Cd [46]. It was found that there was depletion in monocytes and lymphocytes but an elevation in neutrophils and thrombocytes in blood suggesting a reduction in the activation of immune defense mechanisms.

\section{Metallothioneins- The Scavenger and Savior Proteins}

Toxic metals are ubiquitous in our environment, and heavy metals such as cadmium, lead, and mercury have no essential biochemical roles, but exert diverse, severe toxicities in multiple organ systems as they bind in tissues, create oxidative stress, affect endocrine function, block aquaporins, and interfere with functions of essential cations such as magnesium and zinc. Discharge of heavy metals to water streams potentially affects different stages of the aquatic food chain as aquatic flora and fauna tends to accumulate metals. The metal accumulation does not necessarily indicates deleterious effects since organisms have possibilities to protect themselves from metal toxicity by increased excretion, differential allocation among organs and by binding the metals intracellularly [47]. Stress indices or stress biomarkers are used to evaluate the effects of heavy metal pollutants on marine organisms (bioindicators). One such important stress biomarker for assessing heavy metal toxicity is Metallothioneins (MTs), which are low molecular weight (6 to $10 \mathrm{kDa}$ ), cysteine-rich (20-30\%), metal binding proteins whose synthesis represents a specific response of the organisms to pollution by heavy metals such as $\mathrm{Cu}, \mathrm{Zn}, \mathrm{Cd}$ and $\mathrm{Hg}$, both under laboratory and field conditions [48]. They also play an important role in detoxification processes implicating toxic heavy metals. Glutathione is another potent chelator involved in cellular response, transport, and excretion of metal cations and is a biomarker for toxic metal overload.

Fish species that differ in their feeding strategies and/or detoxification capacities might accumulate metals to a different extent. Bottom dwelling species such as the gudgeon (Gobio gobio) will be exposed to water, sediment and food whereas pelagic species are mainly exposed via water and food. As a consequence, given the different way of exposure, both metal accumulation and MT-induction might differ among different species, which might be responsible for differences in sensitivity to metals [49]. It was reported that MT's role in detoxification was organ specific in common carp Cyprinus carpio and he reported that gill, kidney and liver tissues could accumulate $\mathrm{Cd}$ and induce MTs differently [50]. In H. mylodon, liver was more sensitive to metal ions than kidney and gill, and the increase of hepatic MTmRNA was dose-dependent. Induction of hepatic MTs by Cd was time-dependent but transient [51]. The above findings were also 
supported by one of our study that assessing the toxicity of Ar2O3 on fresh water fish $C$. caprio, we found that As elevated the expression of MTs in different tissues though liver tissues showed high MT content [42]. In another study, we reported expression of MT in response to time- and dose-dependent accumulation of $\mathrm{Cd}$ in various tissues of fresh water cat fish of Clarias gariepinus when the fish was treated with $\mathrm{CdCl}_{2}$ in the concentration range of 5 to $20 \mathrm{ppm}$ [52].

\section{MTs as Biomarker for Monitoring the Metal Toxicity in Aquatic System}

Owing to its highly inducible expression during exposures to various heavy metals, MTs have been paid much attention as a potential biomarker to monitor the heavy metal pollution of aquatic ecosystem, a major receptor of pollutants especially with relatively high amount of heavy metals. The isolation and characterization of MTs from bioindicator aquatic organisms should have implications for understanding the biological response to pollutants and for environmental biomonitoring. To date the function of MTs has been focused on its role in metal transport, mineral nutrition, metal detoxification and detoxification of other chemicals (xenobiotics). Other possible functions of MT such as its role in embryonic development, cell differentiation and preventing carcinogenesis via inhibiting metal induced ROS generation require identification and characterization of MTs from other metal binding proteins, and a few reports are available on the studies. Hence, we developed a software program "G primer" to compute primers for MT genes [53]. Given a nucleotide sequence, the program identifies the functionally active regions of MT for gene amplification. Primer selection in Gprimer is specifically built for MT genes without intronic region occurrence. The program has built-in database of functionally active sites, where MT genes are classified based on their respective phylum. To characterize MTs, we developed a computer program "ID3 algorithm" wherein isolated and purified MT proteins were subjected to conditions such as (1) protein with low molecular weight/high molecular weight, (2) proteins with metal content/without metal content, (3) aromatic amino acids/without aromatic amino acids and (4) sulphur content/without sulphur content. The derived conditions at every step were trained in an expert system (ID3 algorithm) [54]. The conditions were then formulated into an IF-THEN-ELSE algorithm and translated into VISUAL BASIC language statements. The developed software solution proposes to categorize MT proteins without aromatic amino acids and high metal content and the solution can be expanded to other types of proteins with specific known characteristics.

\section{BiotoxicEffects of Heavy Metals}

The biotoxic effects of heavy metals are observed in the body when they are consumed above the bio-recommended limits. Although individual metals exhibit specific signs of their toxicity, the following have been reported as general signs associated with cadmium, lead, arsenic, mercury, zinc, copper and aluminium poisoning: gastrointestinal (GI) disorders, diarrhoea, stomatitis, tremor, allergic dermatitis, bronchitis, hemoglobinuria causing a rust-red colour to stool, ataxia, paralysis, vomiting and convulsion, depression, and pneumonia when volatile vapours and fumes are inhaled [55]. The nature of effects could be toxic (acute, chronic or sub-chronic), neurotoxic, carcinogenic, mutagenic or teratogenic, and these effects vary among organisms as well as with the oxidation state of metals. The tolerance limits of some metals are shown in Table 1. Even when the organisms are exposed to heavy metal concentration that is much lower than the permissible limits in their living environments, the metals are accumulated in their body due to continued exposure and xenobiotic food chain biomagnifications [56]. Therefore, a common characteristic of toxic metals is the chronic nature of their toxicity. Hence, elucidating the mechanistic basis of heavy metal interactions in physiological system is essential for assessing health risk.

\begin{tabular}{|c|c|c|c|c|}
\hline $\begin{array}{c}\text { Heavy } \\
\text { metal }\end{array}$ & $\begin{array}{c}\text { Max. conc } \\
\text { in air } \\
(\mathbf{m g} / \mathbf{m} 3)\end{array}$ & $\begin{array}{c}\text { Max. conc } \\
\text { in soil } \\
(\mathbf{m g} / \mathbf{K g} \text { or } \\
\mathbf{~ p p m})\end{array}$ & $\begin{array}{c}\text { Max. conc } \\
\text { in drinking } \\
\text { water } \\
\text { (mg/L) }\end{array}$ & $\begin{array}{c}\text { Max. conc in aquatic } \\
\text { water supporting life } \\
\text { (mg/L or } \mathbf{~ p p m})\end{array}$ \\
\hline $\mathrm{Cd}$ & $0.1-0.2$ & 85 & 0.005 & 0.008 \\
\hline $\mathrm{Pb}$ & $\mathrm{NA}$ & 420 & 0.01 & 0.0058 \\
\hline $\mathrm{Zn}$ & $\mathrm{NA}$ & 7500 & 5 & 0.0766 \\
\hline $\mathrm{Hg}$ & $\mathrm{NA}$ & $<1$ & 0.002 & 0.05 \\
\hline $\mathrm{Ca}$ & 5 & Tolerable & 50 & Tolerable > 50 \\
\hline $\mathrm{Ag}$ & 0.01 & NA & 0 & 0.1 \\
\hline $\mathrm{Cr}$ & 0.005 & NA & 0.1 & 0.02 \\
\hline $\mathrm{As}$ & $\mathrm{NA}$ & $\mathrm{NA}$ & 0.01 & NA \\
\hline
\end{tabular}

Table 1: Maximum contamination levels for heavy metal concentration in air, soil and water according to United States of Environmental Protection Agency (USEPA) and Occupational Safety and Health Administration's permissible exposure limits (OSHA PEL).

\section{Air, Water and Soil Pollution Study in Industrial Units Using Environmental Flow Diagram}

Industry is a major consumer of natural resources and a major contributor to the overall pollution load including the heavy metals and organics. More than $60 \%$ of annual greenhouse gas emissions are related to the industrial activities in the world (transportation fuels and distribution $25.3 \%$, power stations $21.3 \%$ and industrial process 16.8\%) [57]. According to the OECD (Organization for Economic Cooperation and Development) estimates, industries account for about one-third of global energy consumption, and $>10 \%$ of the total fresh water withdrawal thus creating a negative environmental impact in terms of energy crisis and lack of green processes. The degradation of surface and groundwater quality is due to the release of untreated or partially treated industrial effluents or urban wastes into a water body. Ecological flow diagram shows the release of heavy metals into the biosphere comprising air, soil and aquatic environmental systems due to natural and anthropogenic processes, their accumulation in flora and fauna, and the flow cycle of heavy metals (Figure 1).

Studies such as computational and mathematical models as well as designs on environmental management such as Bayesian and DAVID influence diagrams, Hasse diagram (ProRank), and multivariate statistical techniques were reported on the pollution load in air, soil and water and environmental management are available separately but they lack the comprehensive approach in addressing the net pollution effect on the entire biosphere [58]. Besides, these studies were focusing more on the forecasting and management using conventional methods rather than addressing real-time challenges and input-output auditing of pollution load. 


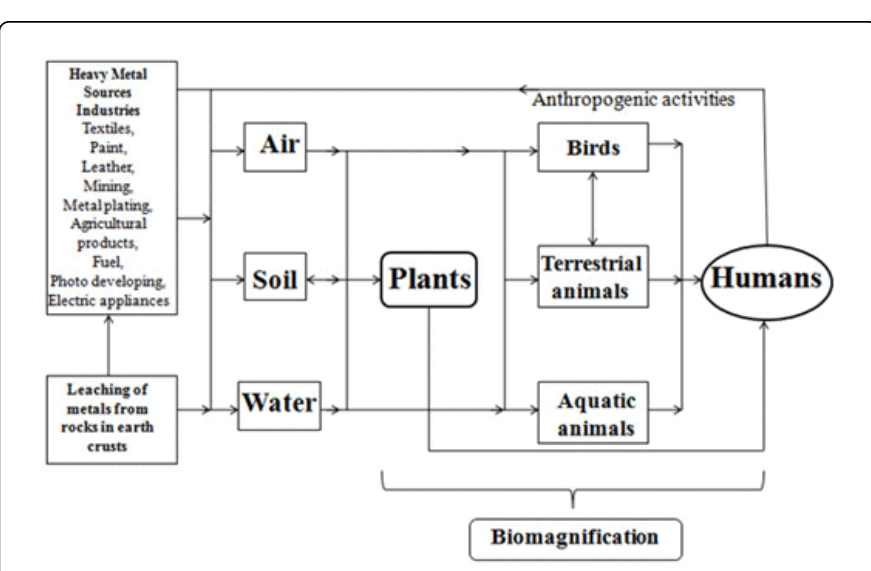

Figure 1: Ecological flow diagram of heavy metals impacting the environment and living systems.

It is important to have information on the quality and quantity of pollution elements generated from the pollution sources to reduce as well as to eliminate the risk of pollution to the living systems. Environmental flow diagrams (EFD) are useful for determining the sources of a range of pollutants, flow of pollutants from sources to acceptor environments, and analyzing the impact of energy optimization solutions to reduce pollutants in process and in field. The diagrams are made based on the energy reference system (RES) and the process flow diagram (PFD) for each industrial firm or unit. RES represented all energy levels such as extraction, collection, primary and final processing, separation, conversion, storage, transmission, distribution, loading, and end-users of energy carriers. An user friendly EFD software to analyze the pollution flow and impact from industries was developed comprising the features of Health, Safety and Environment (HSE) aspects of operational units for providing detailed knowledge of pollution level in industrial areas and the nearby environment $[57,58]$

Heavy metal pollution in water using multivariate statistical techniques was assessed in industrial areas in India [59]. This study used multivariate statistical techniques for evaluation and interpretation of the data with a view to get better information about the water quality and designs some remedial techniques to prevent the pollution caused by hazardous toxic elements in future. Soil magnetometry was used for mapping particulate pollution loads in urban forests and it was reported that very low soil $\mathrm{pH}$ favored the release of heavy metals and other toxic elements into the soil environment, and through the soil, directly into the forest ground flora and underground water system [60]. However, these studies were unidirectional and several factors of pollution aspects were not taken into consideration. The emerging new technology platforms that use computational EFD softwares will help to deal better with environmental challenges in civil and energy engineering projects than the conventional cumbersome methods [61]. EFD softwares were useful in examining pollution indicators such as greenhouse gases and air pollutants in atmosphere and $\mathrm{BOD}, \mathrm{COD}$, heavy metals, organics, and total hardness in water and soil environments. Methods of air pollution estimation in EFD include sampling of emission sources, emission factors available in international resources, engineering calculations, and process simulation. In addition, mode of evaluating water and wastewater qualities in EFD include sampling of industrial wastewater in operational area, comparison with national and international standards, and detecting pollutants that are above environmental standards.

\section{Development of Strategic Approach for Vector Control}

Mosquitoes are known vectors of several disease-causing pathogens, which affect millions of people worldwide causing huge morbidity and mortality. Aedes aegyptĩs known to transmit viral infections such as dengue, yellow fever and chikungunya; Aedes albopictus is known to carry both dengue and chikungunya viruses and can co-transmit the pathogens. Malarial parasites are carried by Anopheles stephensi; and filarial disease by Culex quinquefasciatus. To prevent or to reduce the burden of mosquito-borne diseases and improve public health, it is necessary to control them. Vector control, which includes both antilarval and anti-adult measures, constitutes an important aspect of any mosquito control programs. In recent years, however, mosquito control programs have been suffering from failures because of the ever-increasing insecticide resistance of these vectors [62]. Besides, the recalcitrant chemical insecticides that are currently used in several tropical countries impact severely the both terrestrial and aquatic life systems due to biomagnification and food chain entry.

Biological control of mosquitoes using plant based bioinsecticides has become one of the most important alternatives to prevent development of these vectors as well as reduce the trend of insecticide resistance among them. In addition to the efficiency, they are relatively safe, degradable and readily scalable compared to the problems associated with synthetic insecticides. Several groups of phytochemicals such as alkaloids, steroids, terpenoids, essential oils and phenolics from different plants have been reported for their mosquitocidal activities and several of these are toxic secondary metabolites. When mosquitoes feed on the metabolites, they develop non-specific effects on a wide range of molecular targets. These targets range from proteins (enzymes, receptors, signaling molecules, ionchannels and structural proteins), nucleic acids, biomembranes, and other cellular components [63]. This in turn, affects mosquito physiology in several ways such as abnormality in the nervous system e.g., inhibition of acetylecholinestrase (by essential oils), GABA-gated chloride channel (by thymol), hormonal balance disruption, mitotic poisoning (by azadirachtin), disruption of the molecular events of morphogenesis and alteration in the behaviour and memory of cholinergic system (by essential oil) .

Though many studies on plant extracts against mosquito larvae have been conducted around the world, we present our efforts on the development of a range of ecofriendly bioinsecticides in this review [64-66, 68-72]. The methanolic extract of leaves from Acalypha alnifolia exhibited larvicidal activity against three important mosquitoes such as malarial vector, Anopheles stephensi, dengue vector, Aedes aegypti and Bancroftian filariasis vector, Culex quinquefasciatus [64]. The larval mortality was observed after $24 \mathrm{~h}$ exposure. The early fourth instar larvae of $A$. stephensihad $\mathrm{LC}_{50}$ and $\mathrm{LC}_{90}$ values in the range of 125 to $200 \mathrm{ppm}$ and 390 to $460 \mathrm{ppm}$, respectively. The $A$. aegypti had $\mathrm{LC}_{50}$ and $\mathrm{LC}_{90}$ values in the range of 150 to $200 \mathrm{ppm}$ and 380 to $480 \mathrm{ppm}$, respectively. The $C$. quinquefasciatus had $\mathrm{LC}_{50}$ and $\mathrm{LC}_{90}$ values in the range of 140 to 200 ppm and 390 to $460 \mathrm{ppm}$. This was the first report on the larvicidal activities of South Indian plant extracts against three species of mosquito vectors. The whole plant extracts of Leucas aspera and Bacillus sphaericus was found to be effective against the first to fourth instar larva and pupa of the malarial vector, Anopheles stephensi [65]. A. stephensi had $\mathrm{LC}_{50}$ in the range of 9 to $11 \%$ and $12 \%$ for larvae (for 
4 instars) and pupae, respectively while treating with ethanolic extract of $L$. aspera; the vector had $\mathrm{LC}_{50}$ in the range of $0.051 \%$ to $0.062 \%$ and $0.073 \%$ for larvae and pupae, respectively while treating with $B$. spaericus. The use of $B$. sphaericus as a potential biolarvicides is limited due to the development of resistance by the target mosquito species. However, there are no reports on resistance against plant based bioinsecticides.

The larvicidal and pupicidal effects of leaf extract of Carica papaya were tested against chikungunya and dengue vector, Aedes aegypti; the $\mathrm{IC}_{50}$ values for larval instars (I to IV) ranges between 50 to $82 \mathrm{ppm}$, and for pupae, it was $440 \mathrm{ppm}$ [66]. When the extract was combined with bacterial insecticide, spinosad, the treatment increased the pupicidal efficacy i.e., $\mathrm{LC}_{50}$ : $107 \mathrm{ppm}$. The larvicidal and pupicidal activities were attributed to carpain and papain phytochemicals in the extract. The extracts of Carica papaya leaves not only derive importance in anti-vector properties but also antiviral activities especially against arboviruses such as dengue [67]. The combination of ethanol extract from Acalypha alnifolia leaves and fungal insecticide, Metarizhium anisopliae was evaluated for larvicidal and pupicidal properties against the malaria fever mosquito, Anopheles stephensi and the formulation was found to be more effective in exhibiting antimosquito activities than the individual active components $[68,69]$. Another study explored the effects of Jatropha curcas leaf extract and Bacillus thuringiensis israelensis on larvicidal activity against the lymphatic filarial vector, Culex quinquefasciatus [70]. Combination of plant and microbial insecticides not only shows efficiency in vector control at different stages but also reduces the occurrence of insecticidal resistance.

The effects of solvent extracts of Jatropha curcas, Hyptissu aveolens, Abutilon indicum, and Leucas aspera were tested against third instar larvae of filarial vector, Culex quinquefasciatus, and the larval density was reduced in the range of 60 to $99 \%$ when the sewage water was treated with the extracts [71]. The extracts containing the phytocomponents such isovitexin, vitexin, $\alpha$-amyrin, $\beta$-sitosterol, stigmasterol, and campesterol could be responsible for the larvicidal properties of the plants. Sphaeranthus indicus, Cleistanthus collinus and Murraya koenigii leaf extracts were tested against the third instar larvae of filarial vector, Culex quinquefasciatusand the extracts were found to exhibit mortality at 250 to $1000 \mathrm{ppm}$ [72]. The efficacy of several essential oils exhibiting larvicidal and knock down effects against three important mosquito vectors was studied, and it was found that calamus oil, cinnamon oil, citro- nella oil, clove oil, eucalyptus oil, lemon oil, mentha oil and orange oil exhibited $100 \%$ larvicidal activity at $1000 \mathrm{ppm}$ and $100 \%$ knockdown effect at $10 \%$ concentration [73]. The anti-mosquitocidal efficiency of the oils were further improved to 4 folds by preparing a formulation of combining these eight oils in appropriate proportions along with natural Camphor [74,75]. To summarize, an insecticide does not need to cause high mortality on target organisms in order to be acceptable but should be eco-friendly in nature. Synergistic approaches such as application of mosquito predators with botanical blends and microbial pesticides will provide a better effect in reducing the vector population and the magnitude of epidemiology.

\section{Surveillance for Environmental Management Systems}

Vector borne viral diseases such as dengue, chikungunya, Japanese encephalitis (JE) and parasitic diseases such as malaria and filariasis cause considerable disease burden in human population due to their high virulence and pathogenic properties. In tropical countries including India, the chikungunya affected areas overlap with Dengue endemic areas and provide opportunities for mosquitoes to become infected with both viruses [76]. In areas, where both viruses cocirculate, they can be transmitted together causing co-infections with varied atypical clinical manifestations with frequent outbreak recurrence $[77,78]$. It is a major challenge to the health system in adopting or implementing vector and viral control activities via addressing the problems of water management. Hence, control of these infections through effective water management is gaining not only greater clinical significance but also avoiding the formation of vector breeding sites.

Presently, the problems in viral and vector control activities are not effectively addressed due to reasons such as absence of curative therapy and effective safe mosquitocides, rapid urbanization with development of industrial areas, poor water management including storm water drain, inadequate sustainable environmental and waste management programmes, demographic behavior, presence of nondegradable tyres and plastic containers, garbage and increasing public agglomerations result in providing an ideal environment of breeding sites for mosquitoes. The situation demands a constant and effective viral-vector surveillance system and a vigil on water management strategies in urban cities. There is often a correlation between the potential vector breeding sites and endemicity of diseases. Yet, there is no rational way to approach the problem in view of virological and entomological monitoring with respect to mapping, which is envisaged to evolve new directions in both vector and viral control activities. Geographical Information System (GIS) has become a major tool for public health professionals, epidemiologists and environmental scientists to track the status and distribution of health indicators. GIS maps are used to identify the distribution of diseases and its variations over space and time. GIS in the past have been used primarily for the production of digital amps for resource management and management of land information systems. However, in recent times, it has been used in determining health indicators through geosurveillance of diseases and their patterns, city planning and arriving strategies for resource and waste management to prevent epidemics [79].

In vector borne disease management, creation of cluster mapping using GIS can indicate prevalence, incidence, identification of risk factors, prediction of outbreaks, potential niches of viral and vector activities, control measures implemented and the extent of efficiency of implementation etc [80]. Besides, GIS enables to conduct (i) periodic zone-wise entomological survey for the identification of mosquito larval breeding sites and sources, (ii) vector population density during different seasons in urban areas, (iii) isolation of breeding sites of mosquitoes in the zones near human habitats using mosquito indices, (iv) analyze the spread of different dengue serotypes and chikungunya infections in various zones of urban areas and correlate with vector distribution, and (v) topographic and climatic disease data stratification on the basis of location, intensity, type and time of reporting of symptoms to help the health administrators to assess the morbidity levels and disease pattern in any part of the country [81].With this technology, health departments and policy makers can view hot spots of vector and viral activities to initiate disease control and prevention activities. We have reported the use of GIS for forecasting of chikungunya epidemics via correlating the rainfall with the disease outbreak in thirty districts of Tamil Nadu and forecast for chikungunya outbreak [82]. Smoothing methods were adopted to filter the variability in the dataset; we found that the outbreak intensity was not evenly spread throughout the state and the 
districts with the potential of having low, moderate and high outbreak intensity were mapped and correlated with rainfall.

In another study, we identified high prevalent zones of water and vector borne diseases in Chennai Metropolitan, which is the capital city of Tamil Nadu and the outbreak intensity of such diseases was correlated with topographical and climatological factors such as latitude, altitude, zonal areas, temperature, humidity, rainfall, wind velocity and direction, weather and season etc. It was observed that challenges in management of storm water drain could be the reason behind such outbreaks and we proposed that GIS could effectively address the challenges of storm water drain management in urban cities based on the Chennai model [79].

\section{Integrated Information System for Disease and Disaster Management}

The main role of disease surveillance is to predict, observe, and minimize the impact caused by sudden outbreak, epidemic, endemic and pandemic situations, disasters, as well as knowledge empowerment on factors contributing to such circumstances. Also, strengthening of Health Surveillance System in urban cities has become essential in the context of growing population, climatic, environmental and ecological interactions, rapid industrialization and urbanization and changing socio-economic profiles [83]. At present, there are some basic systems available to manage disease surveillance, but there remains a huge gap in availability of an Integrated and alert system at the field level. Capturing outbreak data from the field on a timely basis is a highly critical requirement for effective surveillance. More importantly, the systems available presently are not providing appropriate data on a timely basis to the decision makers or health authorities. This has caused lacunae in the efforts of Public Health Administration departments while managing sudden outbreaks of highly infectious vector borne diseases $[84,85]$. Effective surveillance system is necessary for management of any Public health hazards.

Due to the lack of Integrated Information System available in the public space for recording, analyzing and reporting on emerging diseases and disasters, we developed IDS (Integrated Decision Support) Online system that could meet the need for effectively managing the emerging infectious disease by providing a detailed demographic profile on the incidence of infectious diseases [86]. It is a web based GIS enabled Information system that collects, manages and analyzes the clinical data pertaining to infectious diseases and geographical factors, and provides time to time information to Public Health Authorities. This initiative would bridge the gap between the actual scenarios at the field level and the decision making process at the management level. Also, the data so available would be useful for healthcare professionals and researchers for further research and effective management of future outbreaks. Besides, the system could act as an Effective Reporting Mechanism, which will aid in disaster management.

\section{Drain Water Management and Health Concerns}

Loading of contaminants to surface waters, groundwater, sediments, and drinking water occurs via two primary routes: (1) point-source pollution and (2) non-point-source pollution [87]. Pointsource pollution originates from discrete sources whose inputs into aquatic systems. Examples of point-source pollution include industrial effluents, municipal sewage treatment plants and combined sewagestorm-water overflows, resource extraction (mining), and land disposal sites. But, non-point-source pollution originates from poorly defined sources such as agricultural runoff (pesticides, pathogens, and fertilizers), storm-water and urban runoff, and atmospheric deposition (wet and dry deposition of persistent organic pollutants such as polychlorinated biphenyls (PCBs), mercury and heavy metals) and this type of pollution occurs over broad geographical scales. Globally, contamination of water by chemicals and pathogens poses the most significant health threat to humans, and there have been countless numbers of disease outbreaks and poisonings throughout history due to exposure to untreated water or lack of efficient drain water management system. Proper surface and subsurface drainage to remove excess water in a safe and timely manner plays an important role in controlling water related diseases. Careful control and appropriate reuse of drainage water can help protect the environment and optimize the use of water resources. Establishing an effective drain water management system requires understanding of the primary sources of toxic contaminants in surface waters and groundwater, the pathways through which they move in aquatic environments, factors that affect their concentration and structure along the many transport flow paths, and the relative risks that these contaminants pose to human and environmental health. Understanding the sources, fate, and concentrations of chemicals/pollutants in water, in conjunction with assessment of effects, not only forms the basis of risk characterization, but also provides critical information required to render decisions regarding regulatory initiatives, remediation, monitoring, and management .

The drainage system is an essential part of living in a city or urban area, as it reduces flood damage by carrying water away. When the excess accumulation of water occurs due to natural or industrial phenomena, some water naturally seeps into the ground. The rest makes its way through drainage systems, into rivers, canals and streams and eventually into the bays, or directly to the bays through storm water beach outlets. In areas with houses, commercial and industrial units and roads, there is a need to create alternative ways for this water to drain away. Large amounts of water can build up quickly during heavy rain and storms, and without adequate networked drainage system, this flows towards low-lying land, causing flooding, damage and pollution associated safety risks.

Downstream beneficial uses of any surface water body to which drainage water is added must be protected. For example, the discharge of saline drainage water into a river or lake is not advisable when that surface water body is being used for domestic or agricultural water supplies. However, it is acceptable to discharge drainage water into a large freshwater body but it is necessary to determine the assimilative capacity of the receiving water and identify the constituents in the drainage water to determine the 'safe level' or discharge requirements for the drainage water. The discharge requirements should specify the maximum allowable concentration of each element of pollution concern and the volume of drainage water discharge that is acceptable. There may be a significant or little difference between the quality of the drainage water and that of the receiving water. The dilution capacity of the receiving water varies from place to place and from time to time depending on numerous local conditions and the upstream uses of the receiving water. The discharge of drainage water of a higher quality than the receiving water is generally acceptable.

Improper use as well as inadequate maintenance of drainage structures (road drainage ditches, septic tanks, drainage canals in irrigation schemes, and also drainage water treatment and disposal facilities) are often associated with environmental health problems. 
The health concerns associated with drainage water management can be grouped in three groups: (i) vector-borne diseases; (ii) faecal/orally transmitted diseases; and (iii) chronic health issues related to exposure to agrochemical residues such as pesticides, insecticides etc [88]. Besides, there is often a lack of adequate domestic water supplies and sanitation facilities. Hence, drainage canals or drainage water treatment and disposal facilities are often used for washing, drinking and untreated effluents or other wastes by marginalized sections that facilitates disease transmission. Silting, uncontrolled aquatic weed growth, slow water flow or stagnant pools associated with the resulting wetlands offer ideal breeding conditions for mosquitoes, pathogenic microorganisms such as enteric bacteria, parasites, enteric viruses, parasites, helminthes etc. The issues related to drainage systems and its associated health issues create more challenges to the health, hygiene and sanity measures of developing and under developing countries than developed nations.

\section{Drainage, Water Logging and Salinity}

Drainage may be practiced in conjunction with irrigation for protecting environment from pollutants and obtaining maximum land as well as agriculture productivity. There are several concerns about the sustainability of drainage and irrigation projects besides the water quality issues related to the disposal of drainage water. There are also problems with land degradation due to irrigation induced salinity and water logging. There are instances where saline or high nutrient drainage water caused damage to aquatic ecosystems. Several countries are facing water logging and salinity problems that are intensified by a range of factors including the use of wastewaters for irrigation, unsuitable cropping patterns, heavy rains and floods, lack of inadequate drainage structures, unsustainable management decisions, irrigation systems without paying attention to their adverse impacts on soil and quality of water resources etc [89]. Drainage continues to be a vital and necessary component of agricultural production systems since excess water/water with high salinity in the crop root zone soil is injurious to plant growth. Crop yields are drastically reduced on poorly drained soils or prolonged water logging as plants eventually die due to lack of oxygen in the root zone [90]. In order to enhance the net benefits of drainage systems, more attention needs to be given to the water quality impacts of drainage water disposal. An efficient drainage system removes salts added to the soil brought in by irrigation water. Various problems such as the increase in soil salinity, water logging, and water table rise into the crop root zone are encountered when an efficient drainage system is not provided in an irrigated area [91].

\section{Drainage Systems Useful for Managing Soil Environmental Crisis}

Various drainage systems have been used to drain the excess water both on the surface and between the soil horizons in order to keep the water table below a certain level and they comprise surface and subsurface drainage infrastructures [92].

\section{Surface Drainage Systems}

Drainage of stationary water on soil surface that can increase water table in the soil profile and harm plant root zone is accomplished by providing surface drainage (surface runoff) system. Surface drainage is often achieved by land forming and smoothing to remove isolated depressions, or by constructing parallel ditches. Ditches and furrow bottoms are gently graded and discharge into main drains at the field boundary. Although the ditches or furrows are intended primarily to convey excess surface runoff, there is some seepage through the soil to the ditches, depending on the water table position. This could be regarded as a form of shallow subsurface drainage. Surface drainage is especially important in humid regions on flat lands with limited hydraulic gradients to nearby rivers or other disposal points.

\section{Subsurface Drainage Systems}

In contrast to surface drainage system that removes excess water accumulated in the cropped area, the excess water and harmful salt solutions in the soil profile can be removed using subsurface drainage system [91]. These underground systems comprised of drain tile or tubing designed to lower the water table by subsurface flow. The downstream ends of the laterals are normally connected to a collector drain. Subsurface drainage is more effective in salt cleaning in soil profile than surface drainage [93]. Subsurface drainage provides several intangible benefits such as improvement in soil health due to the increased aeration of the soil, increased responses to fertilizer use, reduced mineral imbalances in the soil, reduction in salinity etc. In the areas where subsurface drainage system is not constructed, no efficient surface drainage system can be obtained in the soil profile even if surface drainage system is constructed [94].

\section{Horizontal Drainage Systems}

These systems are used in irrigated arid and semi-arid regions for rescuing saline and waterlogged lands to maintain long-term salt and water balances in the crop root zone. Salinity and water logging of lands are due to buildup of the water table, deep percolation of normal excess water and canal seepage. Buried horizontal pipe drains are installed deeply in arid regions when compared to humid regions for controlling salinity. During irrigation, excess quantity of water against the plant evapotranspiration is applied and this additional quantity of water applied is known as the leaching fraction. Naturally occurring as well as applied salts are then leached from the root zone by this water, and removed from the field via the pipe drains. Deeper drain installation ensures that salts do not rise too rapidly to the soil surface due to capillary action. The amount of irrigation water to be removed is generally less in arid than in humid regions [90].

\section{Vertical Drainage Systems}

These systems use tube-wells to control water logging and salinity and the system is widely adopted by South East Asian countries such as India, Pakistan, Sri Lanka etc. The primary goals of tube-wells are almost similar to that of horizontal drains in terms of extracting groundwater for irrigation. As a result of pumping, the water table is lowered, and salinization due to capillarity is minimized. This situation is ideal where the groundwater is not very brackish or saline, and is therefore suitable for irrigation. In areas where the groundwater is highly saline, the pumped water may be too saline for irrigation, unless mixed with fresher or less saline water. Where the groundwater is too saline for crop production, it must be disposed of.

The design of horizontal and vertical drainage systems is based on the layout, depth and spacing of the drains and is generally carried out using subsurface drainage parameters such as the depth of drain, water table and soil, hydraulic conductivity of the soil and drain discharge [95]. Though several studies on the designs of horizontal and vertical drainage systems were described, these studies were performed 
separately on these two systems without comparing the efficacy of them using anisotropic soils. However, comparative study on these two systems for their suitability in anisotropic soils using EnDrainWin and WellDrain softwares for drain spacing and well spacing, respectively was reported $[95,96]$. The study results showed that horizontal drainage systems were better than vertical drainage systems in terms of higher spacings between drains thus reducing number of drainage and cost. However, vertical drainage systems due to the lower changes in well spacing in different anisotropic soils were suitable for conditions that soil hydraulic conductivity was likely to change. In another study, the En Drain software was used to analyze the drainage parameters on the changes of drain discharge in subsurface drainage systems as scrutiny of inflow to the drains is essential for improving soil environmental conditions [97].

Often, agricultural land drainage consists of a combination of both surface and subsurface systems. At the field scale, subsurface drain pipes and field ditches normally exit to an open main or collector drain. At the regional level, the latter then empties into a river or canals. In some instances, depending on the character of the hydrological basin, main drains may dispose of drainage water to an evaporation pond, to a wetland, or to a saline agriculture/agricultureforestry system. In practice, it is often difficult to differentiate between surface and subsurface drainage because the outflow in drainage ditches or canals is usually a combination of both surface and subsurface flow. The relative proportion of surface and subsurface flow in the total drainage volume depends on many factors. These include rainfall intensity, land surface roughness and slope, vegetation, soil permeability, and ditch or drain tubing spacing and depth. Developing countries, in the last half century, experience rapid strides in the changing practices such as conversion of agricultural lands to construct house and industrial units that impact the efficiency of functioning of drainage, water resource management and agriculture systems. Sustainability in public health and agricultural productivity demands macroeconomic policies on the use of land and resources due to the limited availability of water resources and its vulnerability to exploitation and contamination. Actual agricultural yield as percentage of potential yield was higher for North America, Western and Central Europe, South America and North Africa (50-60\%) than Central America, Eastern Europe and Sub-Saharan Africa $(\leq 30 \%)$, and the wide variation in the yields across continents and nations suggest the need for agricultural water management through policies and incentives [98]. Studies that examined land use policies and agricultural water management in different regions of the world including the Africa in the past half century suggested the need for constructing irrigation and drainage facilities as well as implementation of effective land use policies for improving water resources and crop productivity $[98,99]$. These studies were conducted to analyse data on several indices such as anthropological, agricultural, economical and irrigation and drainage indices obtained from Food and Agricultural Organization (FAO) databases and World Bank Group. Interestingly, these studies revealed drastic variations in the production of crops, provided list of strengths and weakness and emphasized the avoidance of trial and error policies to sustain agricultural productivity and water resources.

\section{GIS Application in Drainage Master Planning and Water Resource Management}

The scope of sustainable management of water resources in drainage systems and agriculture concerns the responsibility of policy makers, technologists, users and public to ensure that water resources are allocated efficiently and equitably and used to achieve socially, environmentally and economically beneficial outcomes [100]. In changing anthropogenic domain, there exists a need to update water conservation systems and improve agricultural practices with less chemo-insecticides and pesticides based on water resource information [101]. Urban drainage master planning, in recent years, depends heavily on spatial-based data to establish the characteristics and performance of both major and minor drainage systems. This data includes the topological and geophysical characteristics of the storm sewer and open channel drainage network, the runoff catchments, and overland flow paths and potential hazard areas associated with flooding during extreme runoff events. In the lack of adequate data and information on the drainage system for an area or a region, remotely sensed satellite image based GIS tools have become of great role in analysis. GIS has become an indispensable, multi-purpose tool for infrastructure master planning that enables sophisticated desktop analyses, efficient simulation model pre- and post-processing, and effective data management and communication, all through the use of intrinsic functionality and readily available on-line utilities. Its applications, in urban planning and water resource management, covers storm and sanitary drainage systems, water distribution and resources such as surface as well as ground water, morphometry of streams, watershed planning, regional groundwater protection, a wide range of agricultural systems, rain harvesting systems, climatic conditions across regions, recycled wastewater, and desalinated water. Besides, features on the thematic presentation of real time data facilitate implementation of appropriate schemes for construction of drainage structures and agricultural water management aspects including irrigation water management in rain-fed agriculture; management of floods, droughts, and drainage; and conservation of ecosystems and associated cultural and recreational values. GIS tools for water resource management function on the following platforms using separate softwares: (a) Data management - includes the tasks of reviewing the geospatial images obtained by remote sensing, editing of catchment and infrastructure data, data on hydraulic features and hydraulic model simulation; (b) analysis - using custom applications developed for water balance analysis and core GIS functions such as geoprocessing, surface modeling and hydrologic analysis of major drainage systems for spatial analysis; and (c) presentation - presenting study findings using thematic mapping and three dimensional models.

The use of GIS was reported to explore the temporal and spatial variations in river water quality and to estimate the influence of watershed land use, topography and socio-economic factors on river water quality and various pollutants [102]. In another study, GIS was used to determine the levels of pollution by organic pollutants, salts, metals and microbial indicators in fresh and saline/brackish environments. In this study, surface quality maps for dissolved oxygen, nitrogen and phosphate contents, metals, and total coliforms were developed to highlight hot-spot areas of pollution [103]. It was reported that geospatial data along with GIS was useful in analyzing the topological elements of drainage systems and in inducing their geomorphologic and hydrologic characteristics [104].

Water resource management is crucial for sustaining the environment as well as the survival of life. It is necessary to find faster and more effective methods to identify and manage sources of pollution and minimize the levels of surface and ground water contamination. In some cases, the contamination has already occurred and the primary focus is clean up. GIS contributes solutions to the above problems and further proves useful in adopting water resource 
policy for promoting a more efficient and equitable allocation of natural and community resources.

\section{Conclusion}

Aquatic ecosystem is in threat due to anthropogenic activities that change the quality of water to a great extent. The researches that we had undertaken in this perspective were presented in this review and the findings revealed the factors and mechanism in causing damage to such a precious ecosystem. The review also gives some clue and scope to the research community for finding new enviro-friendly sustainable solutions for the complex problems associated with water contaminants. This review also encourages researchers working in environmental biology to explore novel eco-management strategies to preserve water ecosystem as water is the elixir of life.

\section{Acknowledgements}

I thank the funding agencies of Govt of India such as Department of Science and Technology (DST), Ministry of Environment and Forests (MoEn), University Grants Commission (UGC), Department of Information Technology (DIT) for their support to undertake the need based research. I am also grateful to the Management of Loyola College for their encouragement. Our special thanks to Dr. S. Sivasubramanian, Scientist for his great help in preparation of the review.

\section{References}

1. Dash MC (1994) Fundamentals of Ecology. Tata McGraw-Hill, New Delhi, India.

2. Sharma BK, Kauai H (1994) Environmental Chemistry. Goel Pub House, Meerut, India.

3. Zou E (1997) Effects of sublethal exposure to zinc chloride on the reproduction of the water flea, Moinairrasa (Cladocera). Bull Environ ContamToxicol 58: 437-441.

4. James R, Sampath K, Selvamani P (1998) Effect of EDTA on reduction of copper toxicity in Oreochromismossambicus (Peters). Bull Environ ContamToxicol 60: 487-493.

5. Kotze P, Du Preez HH, Van Vuren JHJ (1999) Bioaccumulation of copper and zinc in Oreochromismossambicus and Clariasgariepinus from the Olifants River, Mpumalanga, South Africa. Water SA 25: 99-110.

6. Abreu SN, Pereira E, Vale C, Duarte AC (2000) Accumulation of mercury sea bass from a contaminated lagoon (Ria de Aveiro, Portugal). Mar Pollut Bull 40: 293.169.

7. Govind P, Madhuri S (2014) Heavy metals causing toxicity in animals and fishes. Res J Animal, Veterinary and Fishery Sci 2: 17-23.

8. Dallinger R, Kutzky H (1985) The importance of contaminated food for the uptake of heavy metals by rainbow trout (Salmogairdnen) a field study. Oecologia 67: 82-89.

9. Arockiadoss T, Vincent S, Xavier FP, Nagaraja KS, Selvanayagam M (1998) pH-based conductivity studies on fish in a contaminated environment. Bull Environ ContamToxicol 61: 645-649.

10. Gohil MN, Mankodi PC (2013) Diversity of fish fauna from downstream zone of river Mahisagar, gujarat state, India. Res J Animal, Veterinary and Fisheries Sci 1: 14-15.

11. Ambrose T, Vincent S, Cyril Arun Kumar L (1994). Susceptibility of the fresh water fish Gambusiaaffinis (Bird and Girad), Sarotherodonmossambicus (Peters) and Cirrhinusmrigala (Ham.) to zinc toxicity. Indian J Environ Toxicol 4: 29-31.

12. Athikewavan S, Vincent S, Velmurugan B (2006) Accumulation of zinc in the different tissues of the Silver carp, Hypophthalmichthysmolitrix. Poll Res 25(1): 47-49.
13. Everall NC, Mcfarlane AA, Sedgwick RW (1989) The effects of water hardness upon the uptake, accumulation and excretion of zinc in the brown trout, Salmotrutta L. J Fish Biol 35: 888-892.

14. Athikesavan S, Vincent S, Velmurugan B (2006) Histopathological effects of zinc sulphate on gill, liver, intestine and kidney tissues of Hypophthalmichthysmolitrix. Indian J Environ Toxicol 16: 27-31.

15. Athikesavan $S$, Vincent $S$, Velmurugan B, Janardhanan $S$ (2006) Impact of nickel and zinc on protein profile of the Silver carp, Hypophthalmichthysmolitrix. Asian J Microbiol Biotech EnvSci 8: 147-149.

16. Athikesavan S, Vincent $S$, Velmurugan B (2006) Investigation of acute toxicity of zinc sulphate in Silver carp (Hypophthalmichthysmolitrix). Aquacult 7: 331-336.

17. Veldhuizen-Tsoerkan MB, Holwerda DA, Van der Mast CA, Zandee DI (1990) Effects of cadmium exposure and heat shock on protein synthesis in gill tissue of sea mussel, Mytilusedulis. Comp BiochemPhysiol 96: 419-426.

18. Athikesavan S, Vincent S, Ambrose T, Velmurugan B (2006) Nickel induced histopathological changes in the different tissues of freshwater fish, Hypophthalmichthysmolitrix (Valenciennes). J Environ Biol 27: 391-395.

19. Nickel. In Environmental Health Criteria (1991) IPCS (International Programme on Chemical Safety).

20. Ambient water quality criteria for nickel (1980) USEPA (US Environmental Protection Agency). EPA Report 440/5-80-060. p206.

21. Eisler R (1998) Nickel hazards to fish, wildlife, and invertebrates: a synoptic review. US Geological Survey, Biological Science Report: 1998-0001, U.S. Fish and Wildlife Service, USA. p76.

22. Ptashynski MD, Klaverkamp JF (2002) Accumulation and distribution of dietary $\mathrm{Ni}$ in Lake Whitefish (Coregonusclupeaformis). Aquatic Toxicol 58: 249-264.

23. Athikesavan S, Vincent S, Velmurugan B (2005) Genotoxic effect of nickel chloride and zinc sulphate on fish Hypophthalmichthysmolitrix. J Indian Fish Assoc 32: 111-117.

24. Alarifi S, Ali D, Alakhtani S, Al Suhaibani ES, Al-Qahtani AA (2014) Reactive oxygen species-mediated DNA damage and apoptosis in human skin epidermal cells after exposure to nickel nanoparticles. Biol Trace Elem Res 157: 84-93.

25. Morita H, Umeda M, Ogawa HI (1991) Mutagenicity of various chemicals including nickel and cobalt compounds in cultured mouse FM3A cells. Mutat Res 261: 131-137.

26. Sarkar B (1995) Metal replacement in DNA-binding zinc finger proteins and its relevance to mutagenicity and carcinogenicity through free radical generation. Nutrition 11: 646-649.

27. Hartmann M, Hartwig A (1998) Disturbance of DNA damage recognition after UV-irradiation by nickel(II) and cadmium(II) in mammalian cells. Carcinogenesis 19: 617-621.

28. Mary MS, Gopal J, Tata BVR, Rao TS, Vincent S (2008) A confocal microscopic study on colony morphology and sporulation of Bacillus sp. World J MicrobiolBiotechnol 24: 2435-2442.

29. Vincent S, Cyril Arun Kumar L, Mani T, Ambrose T, Selvanayagam M (1995) Heavy metal chromium induced alterations on phosphatases activity in the Indian major carp, Catla catla (HAM). Arch Hydrobiol 135: 283-287.

30. Vincent S, Cyril Arun Kumar L, Ambrose T (1996) Impact of heavy metal chromium on bioenergetics of the Indian major carp, Catla catla (HAM). Poll Res 15: 273-275.

31. Ambrose T, Vincent S, Cyril Arunkumar L (1994) Impact of tannery effluent on primary production in the aquatic macrophytesHydrillaverticillata and Ceretophyllumdemersum. Geobios 21: 89-92.

32. Vincent S, Cruz MM, Thomas AL (2001) Bioremediation of chromium by the aquatic macrophyteCaldesiaparanassipolia (L) Parl. Poll Res 20: 75-77. 
33. Mary Mangaiyarkarasi MS, Vincent S, Janarthanan S, SubbaRao T, Tata BV (2011) Bioreduction of Cr(VI) by alkaliphilic Bacillus subtilis and interaction of the membrane groups. Saudi J BiolSci 18: 157-167.

34. Ye Q, Roh Y, Carroll SL, Blair B, Zhou J, et al. (2004) Alkaline anaerobic respiration: isolation and characterization of a novel alkaliphilic and metal-reducing bacterium. Appl Environ Microbiol 70: 5595-5602.

35. Stewart DI, Burke IT, Mortimer RJG (2007) Stimulation of microbially mediated chromate reduction in alkaline soil water systems. Geomicrobiol J 4: 655-669.

36. Allen T, Rana SV (2004) Effect of arsenic (AsIII) on glutathionedependent enzymes in liver and kidney of the freshwater fish Channapunctatus. Biol Trace Elem Res 100: 39-48.

37. Govind P, Madhuri S, Shrivastav AB (2014) Fish Cancer by Environmental Pollutants, 1st edn. Narendra Publishing House, Delhi, India.

38. Bears H, Richards JG, Schulte PM (2006) Arsenic exposure alters hepatic arsenic species composition and stress-mediated gene expression in the common killifish (Fundulusheteroclitus). AquatToxicol 77: 257-266.

39. Ciardullo S, Aureli F, Raggi A, Cubadda F (2010) Arsenic speciation in freshwater fish: focus on extraction and mass balance. Talanta 81: 213-221.

40. Das S, Unni B, Bhattacharjee M, Wann SB, GangadharRao P (2012) Toxicological effects of arsenic exposure in a fresh water teleost fish, Channapunctatus. African J Biotechnol 11: 4447-4454.

41. Ahmed MK, Habibullah-Al-Mamun M, Parvin E, Akter MS, Khan MS (2013) Arsenic induced toxicity and histopathological changes in gill and liver tissue of freshwater fish, tilapia (Oreochromismossambicus). ExpToxicolPathol 65: 903-909.

42. Kovendan K, Vincent S, Janardhanan S, Saravanan M (2013) Expression of metallothionein in liver and kidney of freshwater fish Cyprinuscarpio var. communis (Linn) exposed to arsenic trioxide. Amer J SciInd Res 4: 1-10.

43. Seok SH, Baek MW, Lee HY, Kim DJ, Na YR, et al. (2007) Arseniteinduced apoptosis is prevented by antioxidants in zebrafish liver cell line. Toxicol In Vitro 21: 870-877.

44. Yang JL (2014) Comparative acute toxicity of gallium(III), antimony(III), indium(III), cadmium(II), and copper(II) on freshwater swamp shrimp (Macrobrachiumnipponense). Biol Res 47: 13.

45. Nunes B, Caldeira C, Pereira JL, Gonçalves F, Correia AT (2014) Perturbations in ROS-related processes of the fish Gambusiaholbrooki after acute and chronic exposures to the metals copper and cadmium. Environ SciPollut Res Int .

46. Vincent S, Ambrose T, Selvanayagam M (1994) Influence of the heavy metals cadmium and chromium on leukocytes of fresh water fish, Catla catla (Ham.) Indian J Environ Toxicol 4: 45-47.

47. Van Campenhout K, Infante HE, Hoff PT, Moens L, Goemans G (2010) Cytosolic distribution of $\mathrm{Cd}, \mathrm{Cu}$ and $\mathrm{Zn}$, and metallothionein levels in relation to physiological changes in gibel carp (Carassiusauratusgibelio) from metal-impacted habitats. Ecotox Environ Safe 73: 296-305.

48. Mieiro CL, Bervoets L, Joosen S, Blust R, Duarte AC, et al. (2011) Metallothioneins failed to reflect mercury external levels of exposure and bioaccumulation in marine fish--considerations on tissue and species specific responses. Chemosphere 85: 114-121.

49. Bervoets L, Knapen D, De Jonge M, Van Campenhout K, Blust R (2013) Differential hepatic metal and metallothionein levels in three Feral fish species along a metal pollution gradient. PLoS One 8: e60805.

50. De Smet H, De Wachter B, Lobinski R, Blust R (2001) Dynamics of $(\mathrm{Cd}, \mathrm{Zn})$-metallothioneins in gills, liver and kidney of common carp Cyprinuscarpio during cadmium exposure. AquatToxicol 52: 269-281.

51. Wang WC, Mao H, Ma DD, Yang WX (2014) Characteristics, functions, and applications of metallothionin in aquatic vertebrates. Marine Pollution 1: 34 .

52. Rose S, Vincent S, Meena B, Suresh A, Mani R (2014) Metallothionein induction in fresh water catfish Clariasgariepinus on exposure to cadmium. International J Pharmacy Pharm Sci 6: 377-383.
53. Thomas PJ, Anand T, Suresh P, Janardhanan S, Vincent S (2006) Designing specific oligonucleotide primers for metallothionein genes. Indian J Biotechnol 5: 120-122.

54. Praveen B, Vincent S, Murty US, Krishna AR, Jamil K (2005) A rapid identification system for metallothionein proteins using expert system. Bioinformation 1: 14-15.

55. Duruibe JO, Ogwuegbu MOC, Egwurugwu JN (2007) Heavy metal pollution and human biotoxic effects. Int J Physical Sci, 2(5), 112-118.

56. Tchounwou PB, Yedjou CG, Patlolla AK, Sutton DJ (2012) Heavy metal toxicity and the environment. EXS 101: 133-164.

57. Valipour M, Mousavi SM, Valipour R, Rezaei E (2013) A new approach for environmental crises and its solutions by computer modeling. The 1st International Conference on Environmental Crises and its Solutions, Kish Island, Iran.

58. Valipour M, Mousavi SM, Valipour R, Rezaei E (2012) Air, water, and soil pollution study in industrial units using environmental flow diagram. J. Basic. Appl. Sci. Res 2: 12365-12372.

59. Krishna AK, Satyanarayanan M, Govil PK (2009) Assessment of heavy metal pollution in water using multivariate statistical techniques in an industrial area: A case study from Patancheru, Medak District, Andhra Pradesh, India. J Hazard Mater 167: 366-373.

60. Magiera T, Strzyszcz Z, Rachwal M (2007) Mapping particulate pollution loads using soil magnetometry in urban forests in the Upper Silesia Industrial Region, Poland. Forest Ecology and Management 248: 36-42.

61. Valipour M, Mousavi SM, Valipour R, Rezaei E (2013) Deal with environmental challenges in civil and energy engineering projects using a new technology. J Civil Environ Eng 3: 127.

62. Thomsen EK, Strode C1, Hemmings K1, Hughes AJ1, Chanda E2, et al. (2014) Underpinning sustainable vector control through informed insecticide resistance management. PLoS One 9: e99822.

63. Ghosh A, Chowdhury N, Chandra G (2012) Plant extracts as potential mosquito larvicides. Indian J Med Res 135: 581-598.

64. Kovendan K, Murugan K, Vincent S (2012) Evaluation of larvicidal activity of Acalyphaalnifolia Klein ex Wild. (Euphorbiaceae) leaf extract against the malarial vector, Anopheles stephensi, dengue vector, Aedesaegypti and Bancroftianfilariasis vector, Culexquinquefasciatus (Diptera: Culicidae). Parasitol Res 110: 571-581.

65. Kovendan K, Murugan K, Vincent S, Barnard DR (2012) Studies on larvicidal and pupicidal activity of LeucasasperaWilld. (Lamiaceae) and bacterial insecticide, Bacillus sphaericus, against malarial vector, Anopheles stephensi Liston. (Diptera: Culicidae). Parasitol Res 110: 195-203.

66. Kovendan K, Murugan K, Naresh Kumar A, Vincent S, Hwang JS (2012) Bioefficacy of larvicdial and pupicidal properties of Carica papaya (Caricaceae) leaf extract and bacterial insecticide, spinosad, against chikungunya vector, Aedesaegypti (Diptera: Culicidae). Parasitol Res 110: 669-678.

67. Sharma N, Mishra D (2014) Papaya leaves in dengue fever: is there scientific evidence? Indian Pediatr 51: 324-325.

68. Murugan K, Kovendan K, Vincent S, Barnard DR (2012) Biolarvicidal and pupicidal activity of Acalyphaalnifolia Klein ex Willd. (Family: Euphorbiaceae) leaf extract and Microbial insecticide, Metarhiziumanisopliae (Metsch.) against malaria fever mosquito, Anopheles stephensi Liston. (Diptera: Culicidae). Parasitol Res 110: 2263-2270.

69. Kovendan K, Murugan K, Vincent S, Barnard DR (2012) Efficacy of larvicidal and pupicidal properties of Acalyphaalnifolia Klein ex Willd. (Euphorbiaceae) leaf extract and Metarhiziumanisopliae (Metsch.) against Culexquinquefasciatus Say. (Diptera: Culicidae). J Biopest 5: 170-176.

70. Kovendan K, Murugan K, Vincent S, Kamalakannan S (2011) Larvicidal efficacy of Jatrophacurcas and bacterial insecticide, Bacillus thuringiensis, against lymphatic filarial vector, Culexquinquefasciatus Say (Diptera: Culicidae). Parasitol Res 109: 1251-1257.

71. Kovendan K, Murugan K, Panneerselvam C, Mahesh Kumar P, Amerasan D, et al. (2012) Laboratory and field evaluation of medicinal 
plant extracts against filarial vector, Culexquinquefasciatus Say (Diptera: Culicidae). Parasitol Res 110: 2105-2115.

72. Kovendan K, Arivoli S, Maheshwaran R, Baskar K, Vincent S (2012) Larvicidal efficacy of Sphaeranthusindicus, Cleistanthuscollinus and Murrayakoenigii leaf extracts against filarial vector, Culexquinquefasciatus Say (Diptera: Culicidae). Parasitol Res 111: 1025-1035.

73. Manimaran A, Cruz M, Muthu C, Vincent S, Ignacimuthu S (2012) Larvicidal and knockdown effects of some essential oils against Culexquinquefasciatus Say, Aedesaegypti (L.) and Anopheles stephensi (Liston). Advances in Bioscience and Biotechnology 3:855-862.

74. Manimaran A, Cruz MMJ, Muthu C, Vincent S, Ignacimuthu S (2013) Repellent activity of plant essential oils formulation against three diseases causing mosquito vectors. J AgricTechnol 9: 845-854.

75. Manimaran A, Cruz M, Muthu C, Vincent S, Ignacimuthu S (2013) Larvicidal and growth inhibitory activities of different plant volatile oils formulation against Anopheles stephensi (Liston), Culexquinquefasciatus Say and Aedesaegypti (L.). International Journal of Phytotherapy Research 3: 38-48.

76. Chahar HS, Bharaj P, Dar L, Guleria R, Kabra SK, et al. (2009) Coinfections with chikungunya virus and dengue virus in Delhi, India. Emerg Infect Dis 15: 1077-1080.

77. Vazeille M, Mousson L, Martin E, Failloux AB (2010) Orally co-Infected Aedesalbopictus from La Reunion Island, Indian Ocean, can deliver both dengue and chikungunya infectious viral particles in their saliva. PLoSNegl Trop Dis 4: e706.

78. Taraphdar D, Sarkar A, Mukhopadhyay BB, Chatterjee S (2012) A comparative study of clinical features between monotypic and dual infection cases with Chikungunya virus and dengue virus in West Bengal, India. Am J Trop Med Hyg 86: 720-723.

79. Sanjeevi Prasad S (2007) Public health issues related to storm water drain in Chennai (Zone 2-3) using GIS as a tool for management. Ph.D thesis. University of Madras, India.

80. Palaniyandi M (2012) The role of remote sensing and GIS for spatial prediction of vector-borne diseases transmission: a systematic review. J Vector Borne Dis 49: 197-204

81. Bouzid M, Colón-González FJ, Lung T, Lake IR, Hunter PR (2014) Climate change and the emergence of vector-borne diseases in Europe: case study of dengue fever. BMC Public Health 14: 781

82. Chakkaravarthy VM, Vincent S, Ambrose T (2011) Novel approach of Geographic Information systems on recent outbreaks of chikungunya in Tamilnadu, India. J Environ SciTechnol 4: 387-394.

83. Thakur JS (2006) Integrated Disease Surveillance - A Key Step to improve public health in India. Indian J Community Medicine 31: 215.

84. Zeng D, Chen H, Lynch C, Eidson M, Gotham I (2004) Infectious disease informatics and outbreak detection. Medical Informatics 359-395.

85. Kant L (2008) Combating emerging infectious diseases in India: orchestrating a symphony. J Biosci 33: 425-427.

86. Antony Raj G, Vincent S, Muthumariappan M (2011) Development of an integrated decision support system (IDS Online) for an effective disease surveillance and disaster management. Int J Pharma and Biosciences 2: B452-458.

87. Ritter L, Solomon K, Sibley P, Hall K, Keen P, et al. (2002) Sources, pathways, and relative risks of contaminants in surface water and groundwater: a perspective prepared for the Walkerton inquiry. J Toxicol Environ Health A 65: 1-142.

88. Fritsch MS (1997) Management of agricultural drainage water quality: Water Reports 13. Food and Agriculture Organization of the United Nations. Madramootoo CA, Johnston WR, Willardson LS (Eds.). Natural Resources and Environment, Italy.

89. Valipour M (2014) Drainage, waterlogging, and salinity. Archives of Agronomy and Soil Science 60: 1625-1640.

90. Madramootoo CA (1997) Management of agricultural drainage water quality: Water Reports 13. Food and Agriculture Organization of the United Nations. Madramootoo CA, Johnston WR, Willardson LS (Eds.).

91. Fayrap A, Koc C (2012) Comparison of drainage water quality and soil salinity in irrigated areas with surface and subsurface drainage systems. Agricultural Research 1: 280-284.

92. Fayrap A, Tonkaz T, Kiziloglu FM (2010) Spatial distribution patterns of ground water levels and salinity in Igdir Plain. In: International soil sciences congress on management of natural resources to sustain soil health and qualityâ $€^{\mathrm{mm}}$ OndokuzMayis University, Samsun, Turkey. p286.

93. Bahceci I, Nacar AS (2008) Subsurface drainage and salt leaching in irrigated land in south east Turkey. Irrig Drainage 57: 1-11.

94. Dunn SM, Mackay R (1996) Modelling hydrological impacts of open ditch drainage. J Hydrol 179: 37-66.

95. Valipour M (2012) A Comparison between Horizontal and Vertical Drainage Systems (Include Pipe Drainage, Open Ditch Drainage, and Pumped Wells) in Anisotropic Soils. IOSR Journal of Mechanical and Civil Engineering 4: 7-12.

96. Valipour M (2013) Comparison of Different Drainage Systems Usable for Solution of Environmental Crises in Soil. In: The 1st International Conference on Environmental Crises and its Solutions, Kish Island, Iran.

97. Valipour M (2013) Scrutiny of Inflow to the Drains Applicable for Improvement of Soil Environmental Conditions. In: The 1st International Conference on Environmental Crises and its Solutions, Kish Island, Iran.

98. Valipour M, Ahmadi MZ, Raeini-Sarjaz M, Sefidkouhi MA, Shahnazari A, et al. (2014) Agricultural water management in the world during past half century. Arch Agron Soil Sci 1-12.

99. Valipour M (2014) Land use policy and agricultural water management of the previous half of century in Africa. Appl Water Sci 1-29.

100. Sustainable management of water resources in agriculture, OECD 2010. DOI 10.1787/9789264083578-en.

101. Valipour M (2013) Need to Update of Irrigation and Water Resources Information According to the Progresses of Agricultural Knowledge. Agrotechnol S10: e001.

102. Chen J, Lu J (2014) Effects of land use, topography and socio-economic factors on river water quality in a mountainous watershed with intensive agricultural production in East china. PLoS One 9: e102714.

103. Wilbers GJ, Becker M, Nga LT, Sebesvari Z, Renaud FG (2014) Spatial and temporal variability of surface water pollution in the Mekong Delta, Vietnam. Sci Total Environ 485-486: 653-65.

104. Saud MA (2012) Use of remote sensing and GIS to analyze drainage system in flood occurrence, Jeddah - Western Saudi coast, drainage systems, Prof. Muhammad SalikJavaid (Ed.). 